\title{
New Tools for Studying Network Industry Reforms in Developing Countries: The Telecommunications and Electricity Regulation Database
}

\author{
Scott Wallsten, George Clarke, Luke Haggarty, Rosario Kaneshiro, \\ Roger Noll, Mary Shirley, Lixin Colin Xu*
}

World Bank Policy Research Working Paper 3286, April 2004

The Policy Research Working Paper Series disseminates the findings of work in progress to encourage the exchange of ideas about development issues. An objective of the series is to get the findings out quickly, even if the presentations are less than fully polished. The papers carry the names of the authors and should be cited accordingly. The findings, interpretations, and conclusions expressed in this paper are entirely those of the authors. They do not necessarily represent the view of the World Bank, its Executive Directors, or the countries they represent. Policy Research Working Papers are available online at http://econ.worldbank.org.

\footnotetext{
* Contact information for Scott Wallsten: AEI-Brookings Joint Center, 1150 Seventeenth Street, N.W., Washington, DC 20036. Fax: 202-8627169. Tel: 202-862-5885. Email: $\underline{\text { swallsten@aei.org }}$

Contact information for George Clarke: Development Research Group - Competition Policy and Regulation, World Bank, MSN MC3-300, 1818 H Street, NW, Washington, DC 20433. Fax: 202-522-1155. Tel: 202-473-7454. Email: gclarke@worldbank.org.
} 


\section{Introduction}

Infrastructure industries - including telecommunications, electricity, water, and gas underwent massive structural changes during the 1990s. During that decade, hundreds of privatization transactions valued at billions of dollars were completed in these sectors in developing and transitional economies, or DTEs (Table 1). While privatization has received the most attention in both the popular and academic literature, reforms have involved more than just privatization. They have also included market liberalization, structural changes like unbundling, and the introduction of new laws and regulations.

Until recently, infrastructure sectors were generally considered "natural monopolies," meaning that people believed that a single firm could provide service at the lowest cost. As a result, most countries restricted entry, allowing single firms, which were usually state-owned, to provide service in each industry. ${ }^{1}$ Even after technological progress made the natural monopoly argument less tenable-especially in the telecommunications sector-these firms typically retained a dominant, and often monopoly, position in most countries. Privatization therefore meant creating a private firm capable of exercising significant market power. In other words, even when competition was feasible, the presence of a dominant firm often made its introduction difficult. Regulatory agencies and regulations thus became an integral component of reform as a means of protecting consumers, reassuring investors, and, presumably, helping to advance competition. $^{2}$ Nonetheless, in developing countries the design of regulatory policies and structures to govern infrastructure industries after privatization was often given relatively little attention compared with privatization itself (see Kessides 2003 for a comprehensive overview of regulation in DTEs).

Several factors may help explain the relatively low weight given to regulation. First, fiscal crises often motivated reforms, making many believe that it was important to privatize

\footnotetext{
${ }^{1}$ In the telecommunications sector, single enterprises usually provided service over the entire country. In other sectors, such as water, although there were often multiple providers within any country, they usually had a monopoly in the region where they provided service

${ }^{2}$ While the phrase "regulation" is quite broad, we focus on regulatory agencies that deal with privatized infrastructure; that is, "utilities which require a fixed network to deliver their services" (Newbery 1999). It is worth noting, though, that other types of regulation in developing countries are beginning to receive attention in the literature, as well. For example, Djankov, et al (2002) attempt to measure how regulations affect firm entry in general.
} 
quickly. $^{3}$ While privatization transactions are by no means simple, they are in many respects more straightforward than designing regulations and regulatory agencies. Speed thus meant privatizing first and worrying about regulation later. ${ }^{4}$ Second, there was concern that regulatory agencies would simply become a new mechanism through which the state could interfere with the market. ${ }^{5}$ Finally, industrial countries were beginning to realize the costs of regulation and were rapidly deregulating industries where there appeared to be little economic reason for it (Winston 1993). In that context it could have seemed somewhat hypocritical to advocate new regulatory authorities in transition and developing countries while dismantling them in industrial countries.

Just as designing and implementing regulation was subordinate to the privatization itself, empirical research has also focused far more heavily on privatization than it has on regulation. While some case studies have explored regulation in developing countries, most cross-country empirical work has involved little more than including a dummy variable indicating the presence of a regulator (and perhaps whether the regulator is, in theory, "independent") in a reduced-form regression.

However, regulations, regulators, regulated industries, and politics interact in complicated ways that affect the development of the industry as well as the rest of the economy. The importance of these interactions has long been recognized and debated in the United States - the country with the most experience dealing with private (monopoly) utilities. Indeed, well before privatization became a worldwide phenomenon, an extensive body of literature on regulation had developed in the United States (see, for example, Baron 1989, Braeutigam 1989, Noll 1989, Peltzman 1976, Stigler 1971).

\footnotetext{
${ }^{3}$ Because reform was sometimes motivated in part by the need for revenue, policymakers often tried to maximize revenues by granting temporary monopolies to the privatized utilities, rather than trying to maximize some broader measure of economic surplus or welfare. Such an approach seems to have been successful in increasing investors' valuations of companies, but the monopolies tended to invest less than firms that operated in competitive environments (Wallsten 2000).

${ }^{4}$ The speed of privatizations was debated almost from the start of the privatization trend, with some arguing for speedy privatization (see, for example, Lipton and Sachs 1990), and others arguing for a slower approach with greater emphasis on building regulatory institutions (e.g., Newbery 1991, Summers 1994). While the fast privatization argument generally won out, many now believe it should have been done more slowly (see, for example, Stiglitz 1999).

5 This fear is still a real one. A recent proposal in Russia would have established a single agency to coordinate tariffs in energy, railways, transport terminals, atomic energy, water and air transport, gas and communications-a proposal that sounds remarkably like centralized planning and optimization (Larina 2001).
} 
One reason for the vast body of literature on regulation in industrial countries is the sea of data generated as a byproduct of the interaction of regulatory agencies and regulated firms. Likewise, the main reason for the paucity of empirical work on regulation in developing countries has been the lack of data, which has prevented researchers from exploring regulation in any detail. Our survey of telecommunications and electricity regulators is an attempt to begin to fill this gap by providing systematic data to inform empirical analysis. The survey yields a large dataset that should help promote understanding of regulatory institutions as they actually function and how they interact with the industry and economy.

We are not the first to survey regulators. NERA (1997) conducted surveys of selected infrastructure utility regulators in six countries. ${ }^{6}$ The 12 surveys elicited responses that NERA then interpreted and graded, providing a kind of "scorecard" of regulators. While among the first of its kind, the information gathered tended to be verbal responses rather than data that could easily be compared. And because the 12 surveys were spread over many industries and few countries, the effort generated valuable information, especially for case studies, but not enough to be used for cross-country or cross-industry empirical analysis. ${ }^{7}$ We designed our surveys explicitly to generate data that can inform such empirical work.

\section{Survey Design}

As discussed above, empirical research on infrastructure reforms in developing countries has largely ignored the role of regulation. Moreover, the few papers that have explored regulation have not gone much deeper than controlling for whether a regulatory agency exists, and perhaps whether it is considered "independent." Our survey effort is an attempt to produce data that will allow empirical researchers to explore regulations and regulatory agencies in far more depth than has generally been possible to date. In this section we explain the general framework for designing the surveys. In the following two sections we provide some specific details regarding the telecommunications and electricity surveys, respectively.

\footnotetext{
6 NERA's (1997) survey covered electricity, gas, telecoms, transport, and water in Bangladesh, India, Indonesia, Malaysia, Pakistan, and the Philippines. They did not cover all industries in all countries, so the total number of surveys was 12 .

7 Electricity was the best covered, with four regulatory agencies included. The others each had two. Three regulators were surveyed in India and Malaysia, two in Indonesia and the Philippines, and one each in Bangladesh and Pakistan.
} 
For analytical purposes, regulations can usefully be broken down into governance and content (Levy and Spiller 1994). Governance includes the structures that determine whether those incentives are credible and sustainable. In other words, governance includes rules that order the scope, configuration, and process of regulatory decision-making and the organization and procedures of regulatory agencies (e.g., Levy and Spiller 1996, Williamson 1996). Content includes the specific laws and policies towards pricing, competition, access, and investment that shape incentives facing firms and consumers.

We designed the surveys to capture the large variance in both governance and content. Even basic ideas regarding what is considered important for effective regulatory agencies can take many forms and be subtly different across regulators. For example, it has become almost an article of faith among advisers to developing countries that in order to be effective a regulator must be independent from short-term political pressure. The small amount of empirical research that has investigated the issue typically uses a dummy variable to indicate whether or not a regulator is independent. ${ }^{8}$ Such an approach may be a reasonable first step for empirical research, especially when that dummy variable was the only extant empirical data, but characterizing a regulatory agency as either independent or not independent is unrealistic. No government agency is (or probably should be) completely independent, and can be more or less independent across a wide range of issues.

Thus, rather than ask whether a regulator is independent, we instead ask many objective questions that can help determine how independent a regulator is in different areas. So, for example, among other questions that might be relevant for independence, the survey asks how much of a regulator's budget comes from industries' fees, government appropriations, donors, and other sources; under what circumstances a regulator can be fired; and whether the country's chief executive (president or prime minister) can veto regulatory decisions. Moreover, governance does not end with independence: accountability, transparency, capacity, and competency are also likely to be important features (see, for example, Noll 2000). The surveys contain numerous measures of these criteria, as well. This approach allows researchers to gain a

\footnotetext{
${ }^{8}$ See, for example, Baudrier (2001) or Wallsten $(2001,2002)$. Interestingly, none of these papers finds unambiguously positive effects of independence on sector performance, and finds some evidence of negative effects. These results could be because independence, in fact, is not good for development of the sector, because the regulator dummy variable is likely to be endogenous but is not treated that way in the regressions, because a dummy variable is an unsatisfactory measure of independence, or because independence is only one of many features of governance that work together as a system of checks and balances. The questions raised by these results highlight
} 
better understanding of the nuanced ways in which regulators may or may not be "independent" and how those ways may interact with other governance features (see, for example, Haggarty, Shirley, and Wallsten (2003) who use the telecommunications dataset to explore the extent to which countries meet these criteria and why they may exist in some countries but not others).

\section{Country Selection}

Our intention was to survey all telecommunications and electricity regulators that were operating in developing countries in 2001. We first identified every developing country that seemed to have a regulatory agency with an email address or fax number. We sent the survey via email, fax, and regular mail to those agencies, and followed up with telephone calls. As is made clear below, we had more success with telecommunications regulators than with electricity regulators. This difference in response rates largely reflects the more advanced state of reforms in telecommunications compared to electricity.

\section{The Survey of Telecommunications Regulators}

Between March and August, 2001, we contacted 60 regulatory agencies around the world. We ultimately received responses from 45 countries (Table 2). The result is an extensive database containing 178 variables on regulatory governance and content in 45 countries toward the end of 2001. Not all 45 respondents answered all questions, of course, meaning that the sample size for any given question is typically less than 45. Nonetheless, the survey provides detailed, consistent, comparable data at a level of detail not available before. Appendix 1 contains the survey instrument, coded for use with the dataset.

The survey asked a variety of questions on many aspects of governance and content. On governance respondents provided information on the precise laws affecting the regulatory agency and regulations, as well as several measures of independence, transparency, accountability, capacity, and competency. On regulatory content, respondents provided information on licenses (wireline, wireless, and internet), interconnection, price regulation, and universal service obligations and funding mechanisms. Finally, the survey collected limited

the need both for more empirical work on regulation and the data to do that work. 
information on the state of the sector, including whether and when the incumbent was privatized, and the number of mobile, wireline, and Internet Service Provider licenses applied for, awarded, and active.

Consider, for example, regulatory independence. As discussed above, the survey included various questions on different aspects of independence. One measure of independence is how the regulatory agency is funded. An agency may be less independent if it relies on government allocations. Figure 1 shows how countries tend to finance their regulators. The data show that regulatory agencies tend to receive their budgets either entirely through fees or entirely from a government allocation. Another measure of independence is the direct power the chief executive (typically, the president or prime minister) has over the regulator and regulations. Figure 2 reveals that in slightly more than half the sample countries the chief executive can fire the regulator, while in about 40 percent of the countries the executive can veto the regulators' decisions.

The survey also contains information on regulatory content. Countries commonly regulate prices, for example. Figure 3 reveals that nearly all countries regulate prices of fixedline service, domestic long distance, and international calls. About 40 percent still regulate prices in mobile telephony.

These figures provide a glimpse of the sort of information in the dataset. The myriad data should allow researchers to begin to explore how different types of regulatory governance and content interact with telecommunications reforms to affect the development of the industry. We hope that these data will serve as a first step in exploring empirically the interactions between telecommunications regulation and performance in developing countries.

\section{The Survey of Electricity Regulators}

Electricity reforms have not proceeded as quickly as have telecommunications reforms. It proved more difficult to identify regulatory agencies and to elicit responses from the agencies we identified. Our survey of electricity regulators therefore has fewer observations than does the survey of telecommunications regulators. In the summer of 2001, we identified and contacted 46 regulators by email, fax, and regular mail. We followed up with faxes and telephone calls, and by April 2002 received 20 responses (Table 3). Breaking responses into their individual 
components yields a dataset of 20 observations and 374 variables. As in the telecommunications survey, not all regulators responded to all questions, so not all variables exist for each observation. Appendix 2 provides the complete questionnaire, coded for use with the STATA dataset.

In addition to governance questions of the sort described above, we asked regulatory content questions tailored to the electricity sector. For example, the survey inquires about the state of unbundling of transmission, generation, and distribution. Questions regarding competition, too, are specific to the electricity sector, asking, for example, whether choice of electricity supplier is restricted to consumers of some minimum size-common in early stages of electricity reforms.

Consider the general structure of the industry. The survey asks whether the industry remains a vertically integrated monopoly, whether there is any wholesale competition, and whether supply and retail competition exists. Figure 4 shows that while only about one-quarter of the countries in the sample retain completely vertically-integrated electricity companies, competition is not especially advanced: slightly more than half allow wholesale competition, but only around 15 percent allow retail competition.

\section{Conclusion}

The telecommunications and electricity regulation databases are the product of an effort to generate systematic, rigorous, cross-country data on regulations and regulatory agencies in developing countries. While these data do not approach the quality and quantity of data available for regulated industries in industrial countries, they provide information at a level of detail and for a number of countries not available before. We hope these datasets can contribute substantively to the ongoing reforms of network industries and the debate surrounding the optimal structure of these industries. 


\section{References}

Baron, David P. "Design of Regulatory Mechanisms and Institutions." In Handbook of Industrial Organization, edited by Richard Schmalensee and Robert Willig, 1347-444. Amsterdam: North-Holland, 1989.

Baudrier, Audrey. "Independent Regulation and Telecommunications Performance in Developing Countries." In University of Paris Panthéon-Sorbonne Working Paper. Paris, 2001.

Braeutigam, Ronald R. "Optimal Policies for Natural Monopolies." In Handbook of Industrial Organization, edited by Richard Schmalensee and Robert Willig. Amsterdam: Elsevier, 1989.

Djankov, Simeon, Rafael La Porta, Florencio Lopez-de-Silanes, and Andrei Shleifer. "The Regulation of Entry." Quarterly Journal of Economics 117, no. 1 (2002): 1-37.

Haggarty, Luke, Mary M. Shirley, and Scott Wallsten. "The Structures of Regulatory Governance." Washington, DC, 2003.

Kessides, Ioannis. "Infrastructure Regulation: Promises, Perils, and Principles." Washington DC, 2003.

Larina, Ekaterina. "Ministries Scrap over Single Tariff Authority: Government Seeks Better Regulation of Natural Monopolies." The Russia Journal, August 10-16 2001.

Levy, Brian, and Pablo Spiller. Regulations, Institutions, and Commitment: Comparative Studies of Telecommunications. Cambridge: Cambridge University Press, 1996.

Levy, Brian, and Pablo T Spiller. "The Institutional Foundations of Regulatory Commitment: A Comparative Analysis of Telecommunications Regulation." Journal of Law, Economics, and Organization 10, no. 2 (1994): 201-46.

Lipton, David, and Jeffrey Sachs. "Privatization in Eastern Europe: The Case of Poland." Brookings Papers on Economic Activity, no. 2 (1990): 293-341.

(NERA), National Economic Research Associates. "Governance and Regulatory Regimes for Private Sector Infrastructure Development." Manila, Philippines, 1997.

Newbery, David. Privatization, Restructuring, and Regulation of Network Utilities. Cambridge: MIT Press, 1999.

_. "Reform in Hungary: Sequencing and Privatization." European Economic Review 35, no. 2-3 (1991): 571-80. 
Noll, Roger. "Economic Perspectives on the Politics of Regulation." In Handbook of Industrial Organization, edited by Richard Schmalensee and Robert Willig, 1254-82. Amsterdam: North-Holland, 1989.

—. "Telecommunications Reform in Developing Countries." In SIEPR Policy Paper. Stanford, 2000.

Peltzman, Sam. "Toward a More General Theory of Regulation." Journal of Law and Economics 19, no. 2 (1976): 211-40.

Stigler, George. "The Theory of Economic Regulation." Bell Journal of Economics and Management Science 2 (1971): 3-21.

Stiglitz, Joseph E. "Promoting Competition in Telecommunications." In Centro de Estudios Economicos de lat Regulacion Working Paper Series. Buenos Aires, 1999.

Summers, Lawrence. "Privatization in Eastern Europe: The Case of Poland; Comments and Discussion." Brookings Papers on Economic Activity, no. 2 (1994): 334-41.

Wallsten, Scott. "An Econometric Analysis of Telecom Competition, Privatization, and Regulation in Africa and Latin America." Journal of Industrial Economics 49, no. 1 (2001): 1-20.

—. "Of Carts and Hourses: Regulation and Privatization in Telecommunications Reforms." In Policy Research Working Paper. Washington, DC, 2002.

—. "Telecommunications Privatization in Developing Countries: The Real Effects of Exclusivity Periods." In SIEPR Policy Paper. Stanford, CA, 2000.

Williamson, Oliver E. The Mechanisms of Governance. New York: Oxford University Press, 1996.

Winston, Clifford. "Economic Deregulation: Days of Reckoning for Microeconomists." Journal of Economic Literature 31, no. 3 (1993): 1263-89. 


\section{Table 1}

Infrastructure Privatizations in Developing and Transition Economies (1990-1998)

\begin{tabular}{l|cc}
\hline & $\begin{array}{c}\text { Proceeds } \\
\text { (Millions of US\$) }\end{array}$ & $\begin{array}{c}\text { Number of } \\
\text { Transactions }\end{array}$ \\
\hline Telecommunications & $70,579.40$ & 125 \\
Electricity \& Power & $43,096.24$ & 221 \\
Railways & $4,000.55$ & 30 \\
Ports \& Airports & $2,339.29$ & 54 \\
Roads & $2,121.05$ & 10 \\
Water \& Sewerage & $1,084.66$ & 10 \\
\hline
\end{tabular}

Source: World Bank File data.

Table 2

\begin{tabular}{|ll|}
\hline & \\
\hline \hline Countries in the Telecom Regulators Survey \\
\hline Argentina & Jordan \\
Barbados & Kenya \\
Belize & Latvia \\
Bolivia & Malawi \\
Bosnia and Herzegovina & Malaysia \\
Brazil & Mexico \\
Bulgaria & Moldova \\
Chile & Mongolia \\
Colombia & Morocco \\
Costa Rica & Pakistan \\
Cote d'Ivoire & Panama \\
Czech Republic & Peru \\
Dominican Republic & Poland \\
Ecuador & Romania \\
El Salvador & Slovakia \\
Estonia & South Africa \\
Ghana & Sri Lanka \\
Greece & Tanzania \\
Guatemala & Thailand \\
Honduras & Turkey \\
Hungary & Uganda \\
India & Venezuela \\
Jamaica & \\
\hline & \\
\hline
\end{tabular}


Table 3

\begin{tabular}{|ll|}
\hline \multicolumn{2}{l|}{} \\
\hline \hline Countries in the Electricity Regulators Survey \\
\hline Albania & Hungary \\
Argentina & Indonesia \\
Armenia & Latvia \\
Chile & Malaysia \\
Colombia & Mexico \\
Costa Rica & Nicaragua \\
Czech Republic & Panamá \\
Dominican Republic & Poland \\
Ecuador & Singapore \\
El Salvador & South Africa \\
\hline
\end{tabular}


Figure 1

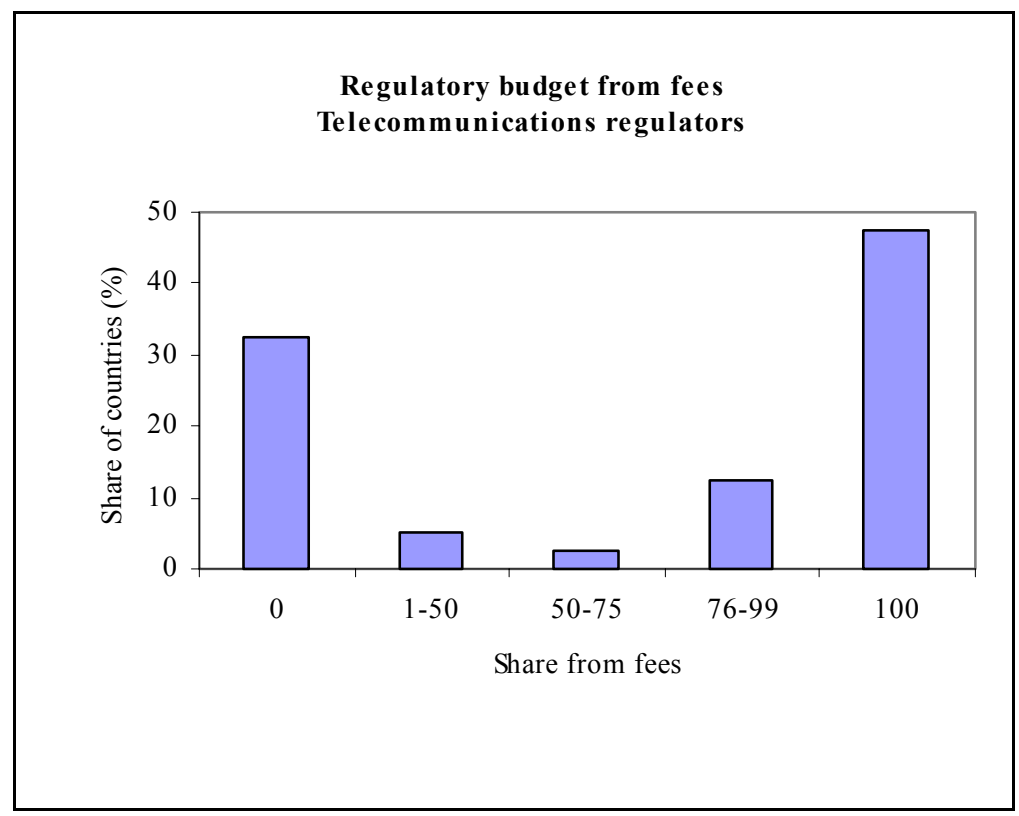

Figure 2

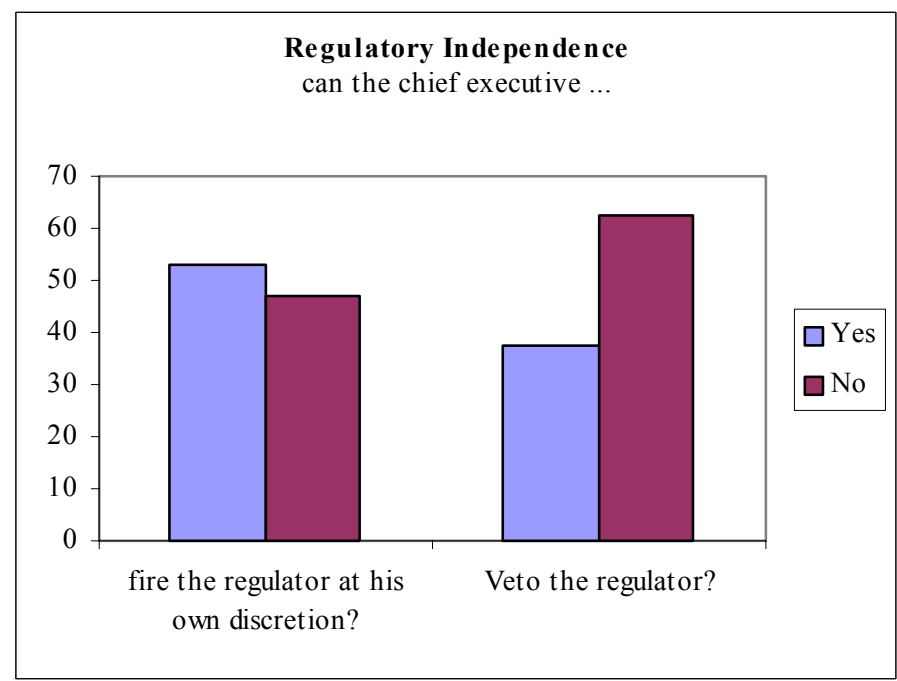


Figure 3

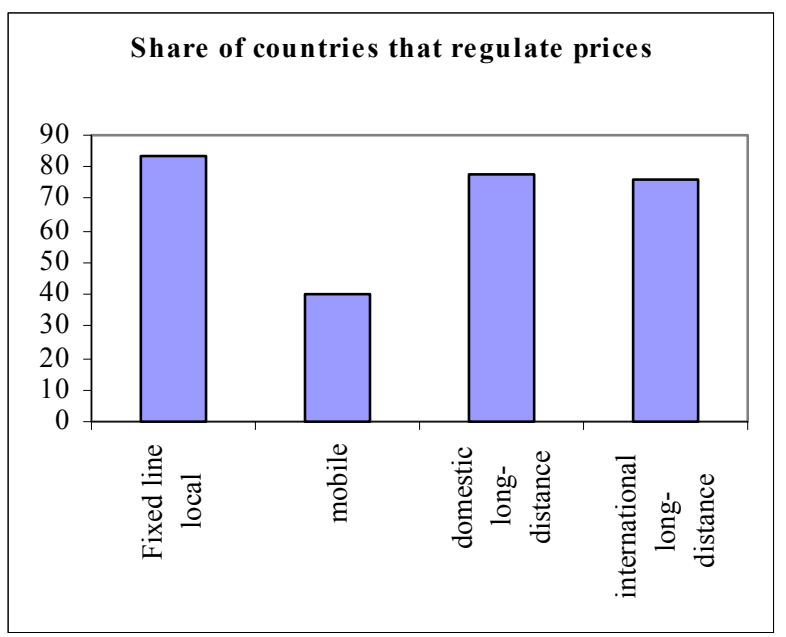

Figure 4

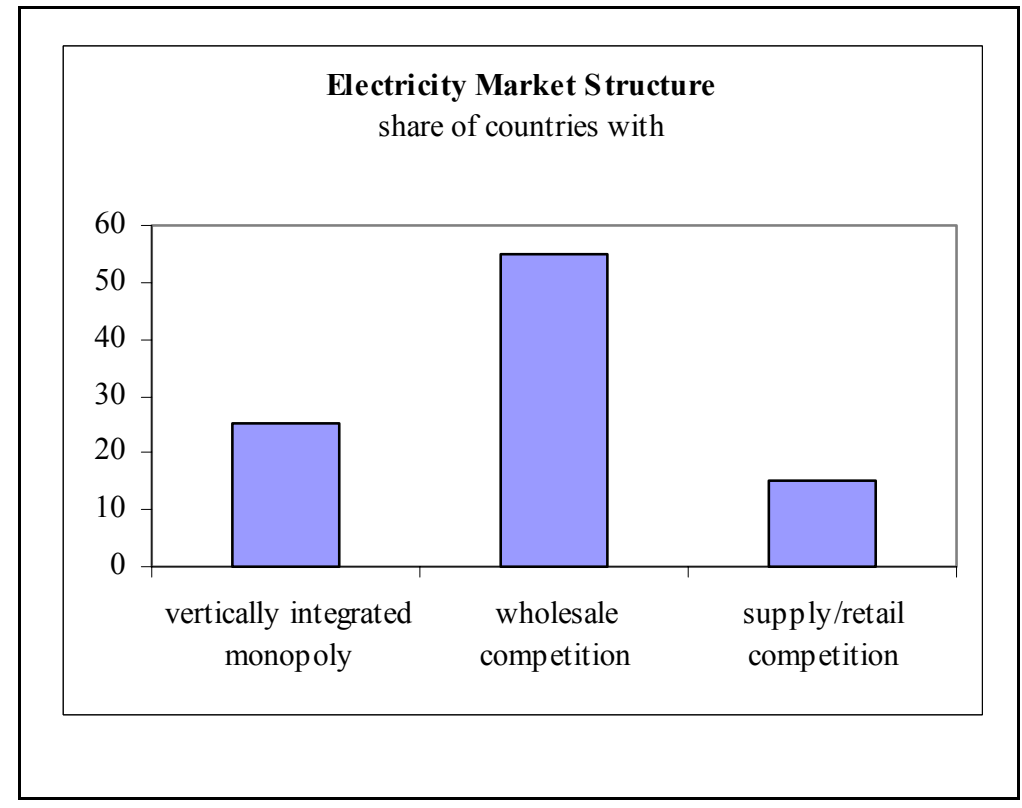




\section{APPENDIX 1 \\ Telecommunications Regulation Survey}

This appendix consists of a copy of the letter sent to regulators to request their participation, as well as the survey itself, coded for use with the STATA dataset.

Code numbers in this appendix are the variable names in the Stata dataset, available here:

http://www.aei-brookings.org/files/telecomregs.dta

An Excel version of the data is available here:

http://www.aei-brookings.org/files/telecom_reg data.xls

$<$ Regulator $>$

$<$ Regulatory Authority $>$

$<$ Address $>$

$<$ Date $>$

Dear Sir,

We are researching the impact of the privatization and liberalization process in the telecommunications sector of emerging economies around the world, and your country has been included for this study.

We kindly request you to fill the attached questionnaire in order to build a database of various telecommunications indicators as part of the study. The questionnaire deals with the following topics:

1. Overall Sector Performance

2. Regulatory Framework

3. Market Structure

4. Licensing Procedure

5. Access and Interconnection Policies

6. Price Regulations

7. Dispute Resolution and Appeals

8. Universal Service Obligations

We would very much appreciate if you could send us the answers to the questionnaire to the above address, Mail stop MC 3-300. Since we are working towards a deadline your timely response would be really helpful. Thank you in advance for your cooperation on this matter.

Sincerely,

George Clarke

Economist

Development Research Group

Competition Policy and Regulation 
Please circle the relevant answer(s) when there are multiple choices.

\section{Section 1. Telecommunications Law.}

1. Has parliament completely passed framework laws for the telecommunications sector? .q1

Yes. Go to Q.1.1

\section{No. Go to Section 2}

1.1 Please list names, years of publication and numbers for all relevant laws, including general laws related to privatization or investment that affect the telecommunications sector.

1. q11

2.

3.

4.

1.2 Does the law explicitly forbid operators from being issued licenses that allow them to provide more than one telecommunication service (such as fixed local telephony, domestic long distance, international long distance and cellular services)? q12 Yes Go to Q.1.4

No Go to Q. 1.3.

1.3 Is separate accounting for services compulsory?

$\underline{\text { Yes }}$ q13

No

1.4 Does the Law allow the telecommunications sector to be privatized in part or in whole?

In Whole 2

In Part 1 q14

Not at all 0

\section{Section 2. Regulatory Bodies}

2. Has a regulatory body $(\mathrm{RB})$ that is separate from the utility and from the communications ministry started work?. q2

$\underline{\text { Yes }}$

No 
Please list all regulatory bodies involved in regulating the telecommunications sector (including the ministry and/or incumbent if they are responsible for some areas of regulation) and the areas of regulation that they are responsible for.

$\underline{\text { Name }}$

Main Regulator.

q2a

2. $q 2 b$

3.

4.

5.

2.1 Does the main regulator have national jurisdiction?

\section{Date of Creation}

q2ay q2br $\mathrm{q} 2 \mathrm{cr}$ q2dr q2er

$\underline{\text { Yes }}$

No q21

$2.2 \quad$ Is the main regulator multi-sectoral?

$\underline{\text { Yes }}$

No q22

2.3 Can the main regulator compel financial and performance information? $\underline{\text { Yes }}$

No q23

2.4 Are financial and performance information publicly available?

$\underline{\text { Yes }}$

No q24

2.5 Does the regulator actually collect the following financial data?

2.5.1 Complete balance sheets from fixed wired operators?

$\underline{\text { Yes/No q251 }}$

2.5.2 Complete income statements from fixed wired operators?

$\underline{\text { Yes/No q252 }}$

2.5.3 Complete balance sheets from cellular operators?

$\underline{\text { Yes/No q253 }}$

2.5.4 Complete income statements from cellular operators ?

$\underline{\text { Yes/No q254 }}$

2.5.5 Complete balance sheets from Internet Service Providers?

$\underline{\text { Yes/No q255 }}$

2.5.6 Complete income statements from Internet Service Providers? Yes/No q256 
2.6 Does the regulator actually collect the following performance indicators?
2.6.1 Call completion rates by operator?
$\underline{\text { Yes/No q261 }}$
2.6.2 Faults/Fault Repair Times?
$\underline{\text { Yes/No q262 }}$
2.6.3 Geographical coverage rates?
$\underline{\text { Yes/No q263 }}$

2.7 Approximately what share of the regulator's budget comes from.

Government Budget
Levies on Companies/License Fees

Donors

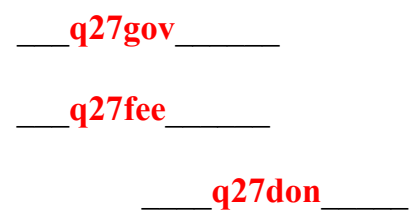

q27oth

Other (Please describe)

\section{$\underline{100 \%}$}

2.8 Is the regulatory body headed by a single person or by a group of people (e.g., a regulatory board)?

Multiple people $\quad$ q28

2.9 How many employees?

q29

Of these:

2.9.1 How many technicians?

q291

2.9.2 How many engineers?

q292

2.9.3 How many accountants?

q293

2.9.4 How many economists?

q294

2.9.5 How many lawyers?

2.10 Who appoints the head of the regulatory body?

295

President

q210

Ministry

Go to 2.11

Parliament

Other (Specify)

Go to 2.11

Go to 2.12

Go to 2.12

2.11If the president or Ministry appoints the head of the regulator body, is Parliamentary approval required?

Yes $\mathrm{q} 211$

No 
No $\quad$ Go to 2.13

$$
\begin{aligned}
& \text { 2.12.1 For how long? } \\
& \text { 2.12.2 Can head be re-appointed? }
\end{aligned}
$$
q2121

$\underline{\text { Yes }} \quad$ q2122

No

2.13 Who appoints the majority of the regulatory body's commissioners? q213

President Go to 2.14

Ministry $\quad$ Go to 2.14

Parliament Go to 2.15

Other (Specify) Go to 2.15

2.14If the president or Ministry appoints the commissioners, is Parliamentary approval required?

$$
\text { Yes q214 }
$$

No

2.15Are commissioners appointed for fixed terms?

$\underline{\text { Yes } \quad \text { Go to 2.15.1 }} \quad q 215$

No Go to 2.16

2.15.1 For how long?

2.15.2 Can head be re-appointed?

$\underline{\text { Yes }} \quad$ q2152

No

2.16Can commissioners be fired?

Yes $\quad$ Go to Q 2.16.1 q216

No Go to 2.17.

2.16.1 Can they be fired at the discretion of the executive? Yes Go to Q 2.17 q2161

No Go to Q 2.16.2.

2.16.2 Can they be fired for conflict of interest?

$\underline{\text { Yes }} \quad \mathrm{q} 2162$

No

2.16.3 Can they be fired for incompetence?

Yes $\quad \mathrm{q} 2163$

No 
No

2.17Can the Minister/President veto the regulator's decisions? $\quad \underline{\text { Yes }} \quad$ q217

No

2.18Can the Minister/President issue written policy guidelines? $\quad \underline{\text { Yes }}$ q218

No

2.19Can the Minister/President issue verbal instructions to the regulator? $\quad \underline{\text { Yes }}$ q219

No

2.20Has the Minister/President issued any written policy guidelines in past year? $\quad \underline{\text { Yes }}$

No

2.21 Circle all groups who have the right to participate in regulatory proceedings: $\mathbf{q 2 2 1}$
(a) Consumers, q221a
(b) Competitors? q221b
(c) Access Users? q221c
(d) others (please list) q221d

2.22Have regional regulatory bodies been created?

Yes q222

No

\section{Section 3. Restructuring}

2.1 Has the incumbent been commercialized and corporatized?

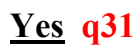

No

2.2 Is the incumbent responsible for providing postal services

$\underline{\text { Yes } \mathrm{q} 32}$

No

2.3 Has the incumbent unbundled any other components (other than postal services)?

Yes q33

No

2.4 Is there any cross-ownership regulation in place?

$\underline{\text { Yes }} \mathrm{q} 34$

No 
2.5 Has the incumbent been privatized?

$\underline{\text { Yes } q 35}$

No

\section{Section 4. Price Regulation}

5.1 Are final-user prices regulated in the following businesses?

5.1.1 Fixed-line local telephony?

5.1.2 Cellular telephony?

5.1.3 Domestic long-distance?

5.1.4 International long-distance?

5.1.5 Internet Service providers? $\underline{\text { Yes/No q411 }}$

$\underline{\text { Yes/No q412 }}$

Yes/No q413

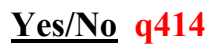

Yes/No q415

5.2 Who approves prices for each service. If there is more than one regulator, please list regulator by name.

1 0

5.2.1 Fixed-line local telephony? $\quad \underline{\text { Regulator/Ministry/President/Parliament. }}$ q421 Name of regulator Other

5.2.2 Cellular telephony? regulator

$\underline{\text { Regulator/Ministry/President/Parliament. }}$ q422 Name of Other

5.2.3 Domestic long-distance? Regulator/Ministry/President/Parliament. q423 Name of regulator Other

5.2.4 International long-distance? regulator

$\underline{\text { Regulator/Ministry/President/Parliament. }}$ q424 Name of Other

5.2.5 Internet Service providers? regulator

Regulator/Ministry/President/Parliament. $q 425$ Name of Other

5.3 How are prices regulated?

5.3.1 Fixed-wire local telephony?

Price Cap

$q 431$

Rate of Return

Global Price Cap

None

Other

5.3.2 Cellular telephony?

Price Cap

Rate of Return

Global Price Cap

None

Other

5.3.3 Domestic long-distance? Price Cap

q433

Rate of Return

Global Price Cap

None

Other 
Rate of Return

Global Price Cap

None

Other

\subsubsection{Internet Service providers?}

Price Cap

Rate of Return

Global Price Cap

None

Other

4.4. Is there a set period of time between regulator reviews?

Yes. Go to Q.4.5 q44

No. Go to Q. 4.6.

4.5. How long (in terms of years) is the period between reviews for the following services?

4.5.1 Fixed-line local telephony? q451

4.5.2 Cellular telephony? q452

4.5.3 Domestic long-distance?

4.5.4 international long-distance?

q454

4.5.5 Internet Service providers? q455

4.6 Does the government subsidize the following services?
4.6.1 Service for low income consumers?
$\underline{\text { Yes/No }}$ q461
4.6.2 Service for rural consumers?
Yes/No q462

5.6 What percentage of subsidies comes from the following sources?

\begin{tabular}{|c|c|c|c|c|}
\hline 5.6 .1 & Budget & & $\%$ & $q 471$ \\
\hline 5.6 .2 & Industry Levies & $\%$ & q472 & \\
\hline 5.6 .3 & Donors & & $\%$ & $q 473$ \\
\hline 5.6 .4 & Other & $\%$ & q474 & \\
\hline
\end{tabular}

\section{Section 5. Interconnection Policies}

6.1 Does the law require that all entrants receive the same technical terms and conditions for access/interconnection?

Yes q51

No 
6.2 Does the law require that all entrants receive the same prices for access/interconnection?

$\underline{\text { Yes }} \mathbf{q 5 2}$

No

6.3 How are access fees/interconnection rates set between the following operators?

5.3.1 Two fixed wired operators $\quad \mathbf{1}=\quad \underline{\text { Bilateral Negotiations }}$

Other, specify:

5.3.2 Incumbent local fixed wired-operator and a cellular operator

\section{Bilateral Negotiations}

Regulator

Other, specify:

5.3.3 Incumbent local fixed wired-operator and long-distance operator

Bilateral Negotiations

Regulator

Other, specify:

5.3.4 Two cellular companies

$\underline{\text { Bilateral Negotiations }}$

Regulator

Other, specify:

5.3.5 Incumbent local fixed wired and an international operator

Bilateral Negotiations

Regulator

Other, specify:

6.4 If any prices are set through bilateral negotiations is there a time limit for those operators to negotiate an agreement?

5.4.1 Two fixed wired operators

5.4.1.1 If yes, how long?

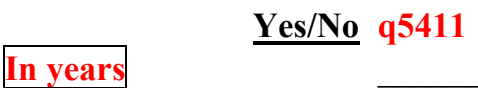

In years

5.4.2 Incumbent local fixed wired-operator and a cellular operator Yes/No q5421
5.4.2.1 If yes, how long? 5.4.2.1 If yes, how long?

5.4.3 Incumbent local fixed wired-operator and long-distance operator $\quad \underline{\text { Yes/No }}$ q5431 5.4.3.1 If yes, how long?

5.4.4 Two cellular companies 5.4.4.1 If yes, how long?

$\underline{\text { Yes/No q5441 }}$

5.4.5 Incumbent local fixed wired and an international operator 5.4.5.1 If yes, how long?

6.5 If the two operators can not agree interconnection/access terms, who intervenes to solve conflicts (if no one can intervene, enter NONE)? q55 


\section{Section 6: Licences}

7.1 Who decides how many licenses will be issued?

Regulator (Name
Ministry
President
Legislature
Privatization Commission
Other

7.2 Is there a formal procedure for granting licenses for the following areas?
7.2.1 Fixed-line local telephony?
$\underline{\text { Yes/No q621 }}$
7.2.2 Cellular telephony?
$\underline{\text { Yes/No q622 }}$
7.2.3 Domestic long-distance?
$\underline{\text { Yes/No q623 }}$
7.2.4 International long-distance?
$\underline{\text { Yes/No q624 }}$
7.2.5 Internet Service providers?
$\underline{\text { Yes/No q625 }}$

7.3 If yes (for each area in q 6.2), is this procedure consistently followed?

7.3.1 Fixed-line local telephony?

7.3.2 Cellular telephony?

7.3.3 Domestic long-distance?

7.3.4 International long-distance?

7.3.5 Internet Service providers?

7.4 Who grant licenses for each area?

7.4.1 Fixed-line local telephony?

7.4.2 Cellular telephony?

7.4.3 Domestic long-distance?

7.4.4 International long-distance?
Yes/No/No Experience q631

$\underline{\text { Yes/No/No Experience q632 }}$

$\underline{\text { Yes/No/No Experience q633 }}$

$\underline{\text { Yes/No/No Experience q634 }}$

$\underline{\text { Yes/No/No Experience q635 }}$ 
Ministry

President

Legislature

$\underline{\text { Privatization Commission }}$

7.4.5 Internet Service providers?

Regulator (Name

Ministry

President

Legislature

Privatization Commission

7.5 For granting a license is there a mandatory bidding?

7.5.1 Fixed-line local telephony?

Yes/No/No Experience q651

7.5.2 Cellular telephony?

Yes/No/No Experience q652

7.5.3 Domestic long-distance?

$\underline{\text { Yes/No/No Experience }} q 653$

7.5.4 International long-distance?

$\underline{\text { Yes/No/No Experience } q 654}$

7.5.5 Internet Service providers?

Yes/No/No Experience q655

7.6 Total number licenses in the following areas?

\section{$\underline{\text { Area }} \underline{\text { Approved Number }} \underline{\text { Awarded Licences }} \underline{\text { Active Operators }}$}

F Fixed-line Local _ _q66Fapp____ _q66Fawd__ _ _

L Domestic Long Distance _q66Lapp____ _q66Lawd____ _ q66 Lact_
I International
-q66Iapp_
_q66Iawd_
_ q66Iact_

C Cellular

_ q66 Capp_

_ q66Cawd__

- q66Cact

ISP Internet Service Providers

_ q66ISPapp__ _ _ q66ISPawd

_ q66ISPact

7.7 What approval do private network operators have to get to before they can start operating?

None q67

Notification

Formal Approval

7.8 What approval do Internet Service Providers have to get before they can start operating?

None

q68

Notification

Formal Approval

7.9 What approval do equipment providers have to get before they can start operating?

None

q69

Notification

Formal Approval

7.10Do equipment providers have to get prices approved?

$\underline{\text { Yes/No q610 }}$ 


\section{Section 7: Spectrum Use}

7.1 Who assigns spectrum?

Regulator (Name

Ministry

q71

President

Legislature

7.2 How is spectrum assigned?

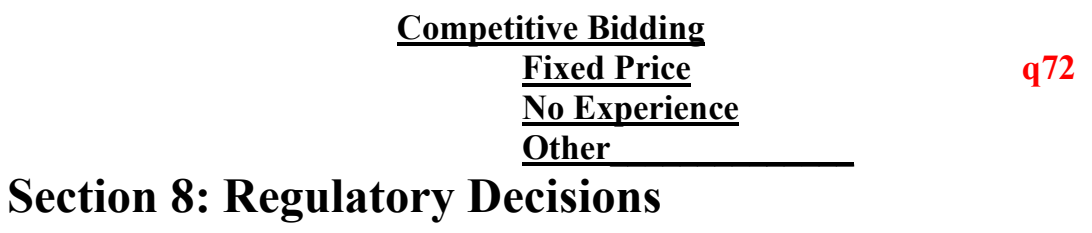

8 Can the operator appeal if disagrees with regulators decision? $\quad \underline{\text { Yes Go to 8.1 }}$ q8

No. Go to 8.3

8.1 Who can the operator appeal to in each instance? (i.e., Ministry, Executive, Other executive body, Judiciary, Formal domestic arbitrator, Formal international arbitrator, no appeal)

8.1.1 First Instance q811

8.1.2 Second Instance $q 812$

8.1.3 Third Instance q813

8.2 Can the operator appeal under the following circumstances

8.2.1 On a statutory basis?

8.2.2 On an evidential basis?

8.2.3 On a procedural basis?

8.3 Can other parties appeal? $\underline{\text { Yes/No q821 }}$

$\underline{\text { Yes/No q822 }}$

$\underline{\text { Yes/No q823 }}$

$\underline{\text { Yes Go to } 8.4}$ q83

No. Go 8.6

8.4 Circle all other parties that can appeal
(a) Access Users
(b) Competitors
(c) Consumers
(d) Others

q84

8.5 Can other parties appeal under the following circumstances

8.5.1 On a statutory basis?

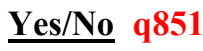

8.5.2 On an evidential basis?

$\underline{\text { Yes/No q852 }}$

8.5.3 On a procedural basis?

Yes/No q853 
8.6 Are regulatory meetings open to the public in practice?

All

Some $\quad$ q86

$\underline{\text { None }}$

8.7 Are regulatory meetings required to be open to the public by law? $\underline{\text { Yes/No }}$ q87

8.8 Are regulatory decisions publicly available? $\quad \underline{\text { Yes/No }}$ q88

8.9 Does regulator publish decisions in practice? $\quad \underline{\text { Yes/No }}$ q89

8.9.1 If so, where?

q891

8.10Does the law REQUIRE the regulator to public decisions Yes/No q810

8.10.1 If so, where? q8101

8.11Does regulator publish explanations of decisions in practice? $\quad \underline{\text { Yes/No }}$ q8_11

8.11.1 If so, where? q8111

8.12Does the law REQUIRE the regulator to publish explanations of decisions Yes/No q8_12

8.12.1 If so, where? q8121

\section{Section 9: Geographically Based Obligations}

9 Does any operator have geography-based obligations?

$\underline{\text { Yes } \quad \text { Go to Q 9.1 q9 }}$

No Go to End

9.1 Do any of the obliged operators have funding from special geographically-based obligations fund? $\underline{\text { Yes/No }}$ q91

9.2 Do all of the obligated operator have access to such funds? $\quad \underline{\text { Yes/No }}$ q92

\section{THANK YOU VERY MUCH FOR YOUR HELP}




\section{APPENDIX 2 \\ Electricity Regulation Survey}

This appendix consists of a copy of the letter sent to regulators to request their participation, as well as the survey itself, coded for use with the STATA dataset.

Code numbers in this appendix are the variable names in the Stata dataset, available here:

http://www.aei-brookings.org/files/electricregs.dta

An Excel version of the data is available here:

http://www.aei-brookings.org/files/electricity_reg_data.xls

Dear Sir/Madame,

As part of our ongoing World Bank Policy Research Report on Infrastructure Regulation, we are conducting a survey of international experience with electricity sector reform. We would like to include your country in this study.

We kindly request you to take a few moments to fill in the attached questionnaire. Our survey covers the following topics:

9. Electricity Sector Characteristics

10. Sector Restructuring

11. Regulatory Framework

12. Regulatory Process/Decisions

13. Pricing Issues

14. Access Policies

15. Universal Service Obligations/Quality of Supply

Your participation in this survey will enhance the quality of the Report. This study will provide policy makers and electricity regulators with insight into effective approaches to regulation and reform based on the experience of a broad panel of countries. We would very much appreciate if you could send us your timely response by email or fax to:

Mr. Tooraj Jamasb

Tel: (202) 4730451

Fax: (202) 5221155

Email: tjamasb@worldbank.org

or alternatively mail to:

Competition Policy and Regulation Team

Development Research Group

Mail Stop MC 3-300,

The World Bank

1818 H Street NW

Washington Dc. 20433, USA

We would welcome any additional material that you may find useful for the purpose of this study. If you have any questions please feel free to contact us.
Mr. Takis Papapanagiotou

Tel: (202) 4735597

Fax: (202) 5221155

Email: tpapapanagiotou@worldbank.org 


\section{Questionnaire for Electricity Regulators}

Please circle or place a cross in front of the relevant answer(s) when there are multiple choices.

\section{Section 1. Electricity Law}

Has the parliament passed any framework laws aiming at reforming the electricity sector?

\section{Q11y (year) No Go to Section 2}

2.23 Please list names, years of publication and numbers for relevant laws, including laws related to privatization or investment that affect the electricity sector.

1._Q Q12a__ Q12ay

2. Q12b

3. Q12C

4. Q12d

5. Q12e

When did the electricity sector reform actually start? (please enter year)_Q13

Does the law explicitly forbid operators from joint ownership of electricity services (such as generation, transmission, distribution, and retail/supply)?... Yes/No Q14

Does the law allow the entry of new private power companies?........... $\quad \underline{\text { Yes/No }}$ Q15

Does the law allow the electricity sector to be privatized in part or in whole?

$2=\underline{\text { In Whole }} \mathrm{Q} 16$

\section{$1=$ In Part}

\section{$0=$ Not at all}




\section{Section 2. Restructuring}

Which of the following market models describes the power sector in your country?

\begin{tabular}{lccc} 
Q21a & \multicolumn{2}{c}{ Vertically integrated monopoly } & $0 / 1$ \\
Q21b & Single buyer market & $\mathbf{0} / \mathbf{1}$ \\
Q21c & Wholesale competition & $\mathbf{0} / \mathbf{1}$ \\
Q21d & Supply/Retail competition & $0 / 1$ \\
Q21e & $=$ Note
\end{tabular}

2.6 Please indicate the years the following reform measures were first initiated in your country:

\begin{tabular}{|l|l|}
\hline Reform measures & \multicolumn{1}{|c|}{ Year } \\
\hline Regulator established & Q22a \\
\hline Privatization & Q22b \\
\hline Vertical separation & Q22C \\
\hline Entry of new private power producers & Q22d \\
\hline Wholesale power market (pool, contract, spot, etc.) & Q22e \\
\hline
\end{tabular}

2.7 Degree of vertical integration from generation to supply

$2=\underline{\text { Unbundled }}$

Q23

2.8 Has transmission been separated from generation? $2=\underline{\text { Separate companies }}$

$$
\begin{aligned}
& \mathbf{1}=\text { Accounting separation } \\
& 0=\underline{\text { Integrated }}
\end{aligned}
$$

Are there vertical restrictions on joint ownership of generation and transmission facilities? Q25

$$
\begin{aligned}
& 1=\text { Yes } \\
& 2=N o
\end{aligned}
$$

2.9 Are there horizontal restrictions on the maximum market share of generation and retail supply companies? $1=\underline{\text { Yes }}$ 
2.11Please fill in the following sector information:

\begin{tabular}{|c|c|c|c|c|c|c|c|c|c|c|c|c|c|c|c|c|c|c|c|}
\hline & & & $\begin{array}{r}\text { At } \\
\text { (In c } \\
\text { il }\end{array}$ & $\begin{array}{l}\text { the } t \\
\text { ase o } \\
\text { nforn }\end{array}$ & $\begin{array}{l}\text { me } \\
\text { Year } \\
\text { no r } \\
\text { ation }\end{array}$ & $\begin{array}{c}\frac{128}{\text { forr }} \\
5\end{array}$ & & $\begin{array}{l}\text { se en } \\
\text { go) }\end{array}$ & nter & & & In $c$ & e of & $\begin{array}{c}\text { Pos } \\
\text { Yea } \\
\text { o ref }\end{array}$ & Ref & $\begin{array}{l}\frac{28 y}{2 y} \\
\text { leas } \\
\text { natio }\end{array}$ & $\begin{array}{l}\text { se ent } \\
\text { on) }\end{array}$ & ter mos & \\
\hline & Q28 & $\mathrm{N}$ & $\begin{array}{l}\text { Numb } \\
\text { Comp }\end{array}$ & $\begin{array}{l}\text { ber o } \\
\text { panie }\end{array}$ & & & 0 of & Tota & al MW & & $\mathrm{N}$ & $\begin{array}{l}\text { Nun } \\
\text { Con }\end{array}$ & $\begin{array}{l}\text { ber } \\
\text { pani }\end{array}$ & & $\mathrm{S}$ & $\%$ & of To & otal MV & \\
\hline & & $\mathrm{a}$ & $\mathrm{b}$ & $\mathrm{c}$ & $\mathrm{d}$ & a & & & $\mathrm{c}$ & $\mathrm{d}$ & $\mathrm{a}$ & $\mathrm{b}$ & $\mathrm{c}$ & d & & & $\mathrm{b}$ & $\mathrm{c}$ & $\mathrm{d}$ \\
\hline & & $\frac{\cdot \frac{0}{3}}{\vec{a}}$ & 胥 & 离 & : & 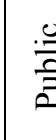 & $\begin{array}{l}\text { 象 } \\
\vdots \\
\vdots\end{array}$ & $\begin{array}{lll}0 \\
2 \\
2\end{array}$ & 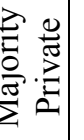 & : & 号 & 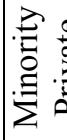 & . & 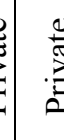 & & E & 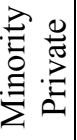 & 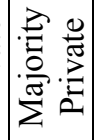 & 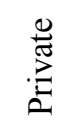 \\
\hline G & Generation & $\begin{array}{l}\mathrm{Q} 2 \\
8 \mathrm{t0} \\
\mathrm{Na} \\
\mathrm{g} \\
\end{array}$ & $\begin{array}{l}\mathrm{Q} 2 \\
\text { 8t0 } \\
\mathrm{Nb} \\
\mathrm{g} \\
\end{array}$ & $\begin{array}{l}\text { Q2 } \\
8 \text { t0 } \\
\text { Nc } \\
\mathrm{g} \\
\end{array}$ & $\begin{array}{l}\mathrm{Q} 2 \\
8 \mathrm{t} 0 \\
\mathrm{Nd} \\
\mathrm{g}\end{array}$ & $\begin{array}{l}22 \\
8 t 0 \\
\text { Sa }\end{array}$ & $\begin{array}{l}\mathrm{Q} \\
8 \\
\mathrm{~S}\end{array}$ & & $\begin{array}{l}\text { Q2 } \\
8 \text { t0 } \\
\text { Scg }\end{array}$ & $\begin{array}{l}\text { Q2 } \\
\text { 8t0 } \\
\text { Sdg }\end{array}$ & $\begin{array}{l}\mathrm{Q} 2 \\
8 \mathrm{~N} \\
\mathrm{ag}\end{array}$ & $\begin{array}{l}\mathrm{Q} 2 \\
8 \mathrm{~N} \\
\mathrm{bg}\end{array}$ & $\begin{array}{l}\mathrm{Q} 2 \\
8 \mathrm{~N} \\
\mathrm{cg}\end{array}$ & $\begin{array}{l}\mathrm{Q2} \\
8 \mathrm{~N} \\
\mathrm{dg}\end{array}$ & & 2 & $\begin{array}{l}\mathrm{Q} 2 \\
8 \mathrm{Sb} \\
\mathrm{g}\end{array}$ & $\begin{array}{l}\mathrm{Q} 2 \\
8 \mathrm{SC} \\
\mathrm{g}\end{array}$ & $\begin{array}{l}\text { Q2 } \\
8 S d \\
g\end{array}$ \\
\hline $\mathbf{T}$ & Transmission & $\begin{array}{l}\text { Q2 } \\
8 \text { t0 } \\
\text { Nat }\end{array}$ & $\begin{array}{l}\mathrm{Q} 2 \\
8 \mathrm{t} 0 \\
\mathrm{Nbt}\end{array}$ & $\begin{array}{l}\text { Q2 } \\
8 \text { t0 } \\
\text { Nct }\end{array}$ & $\begin{array}{l}\mathrm{Q} 2 \\
8 \mathrm{t} 0 \\
\mathrm{Ndt}\end{array}$ & $\begin{array}{l}\mathrm{Q} 2 \\
8 \mathrm{tC} \\
\mathrm{Sa}\end{array}$ & $\begin{array}{l}Q \\
8 \\
S\end{array}$ & & $\begin{array}{l}\text { Q2 } \\
\text { 8t0 } \\
\text { Sct }\end{array}$ & $\begin{array}{l}\mathrm{Q} 2 \\
8 \mathrm{t0} \\
\text { Sdt }\end{array}$ & $\begin{array}{l}\mathrm{Q} 2 \\
8 \mathrm{~N} \\
\text { at }\end{array}$ & $\begin{array}{l}\mathrm{Q} 2 \\
8 \mathrm{~N} \\
\mathrm{bt}\end{array}$ & $\begin{array}{l}\text { Q2 } \\
8 \mathrm{~N} \\
\mathrm{Ct}\end{array}$ & $\begin{array}{l}\mathrm{Q2} \\
8 \mathrm{~N} \\
\mathrm{dt}\end{array}$ & & & $\begin{array}{l}\mathrm{Q} 2 \\
8 \mathrm{Sb} \\
\mathrm{t}\end{array}$ & $\begin{array}{l}\mathrm{Q} 2 \\
8 \mathrm{Sc} \\
\mathrm{t}\end{array}$ & $\begin{array}{l}\mathrm{Q} 2 \\
8 \mathrm{Sd} \\
\mathrm{t}\end{array}$ \\
\hline D & Distribution & $\begin{array}{l}\text { Q2 } \\
\text { 8t0 } \\
\mathrm{Na} \\
\mathrm{d}\end{array}$ & $\begin{array}{l}\text { Q2 } \\
8 \text { t0 } \\
\mathrm{Nb} \\
\mathrm{d}\end{array}$ & $\begin{array}{l}22 \\
8 \text { t0 } \\
\text { Nc } \\
\text { d }\end{array}$ & $\begin{array}{l}\mathrm{Q} 2 \\
8 \mathrm{t} 0 \\
\mathrm{Nd} \\
\mathrm{d}\end{array}$ & $\begin{array}{l}\mathrm{Q2} \\
8 \mathrm{tC} \\
\mathrm{Sa}\end{array}$ & $\begin{array}{l}\mathrm{Q} \\
8 \\
\mathrm{~S}\end{array}$ & & $\begin{array}{l}\text { Q2 } \\
\text { 8t0 } \\
\text { Scd }\end{array}$ & $\begin{array}{l}\text { Q2 } \\
\text { 8t0 } \\
\text { Sdd }\end{array}$ & $\begin{array}{l}\text { Q2 } \\
8 \mathrm{~N} \\
\text { ad }\end{array}$ & $\begin{array}{l}\mathrm{Q} 2 \\
8 \mathrm{~N} \\
\mathrm{bd}\end{array}$ & $\begin{array}{l}\text { Q2 } \\
8 \mathrm{~N} \\
\mathrm{~cd}\end{array}$ & $\begin{array}{l}\mathrm{Q2} \\
8 \mathrm{~N} \\
\mathrm{dd}\end{array}$ & $\begin{array}{l}8 \\
\mathrm{~d}\end{array}$ & & $\begin{array}{l}\text { Q2 } \\
8 \mathrm{Sb} \\
\mathrm{d}\end{array}$ & $\begin{array}{l}\text { Q2 } \\
8 S C \\
d\end{array}$ & $\begin{array}{l}\text { Q2 } \\
8 S d \\
d\end{array}$ \\
\hline $\mathbf{S}$ & Supply & $\begin{array}{l}\text { Q2 } \\
\text { 8t0 } \\
\text { Nas }\end{array}$ & $\begin{array}{l}\text { Q2 } \\
8 \text { t0 } \\
\text { Nbs }\end{array}$ & $\begin{array}{l}\text { Q2 } \\
8 \text { t0 } \\
\text { NcS }\end{array}$ & $\begin{array}{l}\text { Q2 } \\
8 \text { t0 } \\
\text { Nds }\end{array}$ & $\begin{array}{l}\mathrm{Q2} \\
8 \mathrm{tC} \\
\mathrm{Sa}\end{array}$ & $\begin{array}{l}\mathrm{Q} \\
8 \\
\mathrm{~S}\end{array}$ & & $\begin{array}{l}\text { Q2 } \\
\text { 8t0 } \\
\text { Scs } \\
\end{array}$ & $\begin{array}{l}\text { Q2 } \\
\text { 8t0 } \\
\text { Sds }\end{array}$ & $\begin{array}{l}\text { Q2 } \\
8 \mathrm{~N} \\
\text { as }\end{array}$ & $\begin{array}{l}\mathrm{Q} 2 \\
8 \mathrm{~N} \\
\mathrm{bs}\end{array}$ & $\begin{array}{l}\text { Q2 } \\
8 \mathrm{~N} \\
\mathrm{CS}\end{array}$ & $\begin{array}{l}\mathrm{Q2} \\
8 \mathrm{~N} \\
\mathrm{ds} \\
\end{array}$ & & & $\begin{array}{l}\mathrm{Q} 2 \\
8 \mathrm{Sb} \\
\mathrm{s}\end{array}$ & $\begin{array}{l}\mathrm{Q} 2 \\
8 \mathrm{Sc} \\
\mathrm{s}\end{array}$ & $\begin{array}{l}\text { Q2 } \\
8 S d \\
\text { s }\end{array}$ \\
\hline & Total & $\begin{array}{l}\mathrm{Q} 2 \\
8 \mathrm{t0} \\
\mathrm{Na}\end{array}$ & $\begin{array}{l}\mathrm{Q} 2 \\
8 \mathrm{t0} \\
\mathrm{Nb}\end{array}$ & $\begin{array}{l}\mathrm{Q} 2 \\
8 \mathrm{t0} \\
\mathrm{Nc}\end{array}$ & $\begin{array}{l}\text { Q2 } \\
8 \mathrm{t} 0 \\
\mathrm{Nd}\end{array}$ & $\begin{array}{l}\mathrm{Q2} \\
8 \mathrm{tC} \\
\mathrm{Sa}\end{array}$ & $\begin{array}{l}\mathrm{Q} \\
8 \mathrm{t} \\
\mathrm{S}\end{array}$ & & $\begin{array}{l}\text { Q2 } \\
\text { 8t0 } \\
\text { Sc } \\
\end{array}$ & $\begin{array}{l}\text { Q2 } \\
8 \text { t0 } \\
\text { Sd }\end{array}$ & $\begin{array}{l}\mathrm{Q} 2 \\
8 \mathrm{~N} \\
\mathrm{a}\end{array}$ & $\begin{array}{l}\mathrm{Q} 2 \\
8 \mathrm{~N} \\
\mathrm{~b}\end{array}$ & $\begin{array}{l}\text { Q2 } \\
8 \mathrm{~N} \\
\mathrm{C}\end{array}$ & $\begin{array}{l}\mathrm{Q} 2 \\
8 \mathrm{~N} \\
\mathrm{~d}\end{array}$ & & & $\begin{array}{l}22 \\
8 S b\end{array}$ & $\begin{array}{l}\mathrm{Q} 2 \\
8 \mathrm{Sc}\end{array}$ & $\begin{array}{l}\text { Q2 } \\
8 S d\end{array}$ \\
\hline
\end{tabular}

Q28t0NG $=$ total number of generators at time of reform

Q28t0NT = total number of transmission companies at time of reform

Q28t0ND = total number of distribution companies generators at time of reform

Q28t0NS = total number of supply companies at time of reform

2.12Have the public (e.g. central government, state-owned, municipal etc.) company(ies) been corporatized?

$\underline{\text { Yes }}$

$$
\text { Q29 }
$$

$\underline{\text { No }}$

2.13 Are consumers allowed to choose among electricity suppliers?

$$
\text { Q210 }
$$


2.15 Please provide the customer threshold(s) (in $\mathrm{kW} / \mathrm{kWh}$ ) for which consumers are free to choose among electricity producers/suppliers and the date this regulation(s) took (will take) effect: Q212

\begin{tabular}{llcr} 
Customer Type & $\begin{array}{c}\text { Customer Size } \\
(\mathbf{k W} / \mathbf{k W h})\end{array}$ & \%o of Total Consumption & Date \\
& \multicolumn{1}{c}{ (a) } & (b) & (c) \\
Industrial & Q212aI & Q212bI & Q212cI \\
Commercial & Q212aC & Q212bC & Q212cC \\
Residential & Q212aR & Q212bR & Q212cR
\end{tabular}




\section{Section 3. Regulatory Bodies}

3.1 Has a regulatory body that is separate from the utilities and from the Ministry

started to work?.

Q31

$\underline{\text { Yes/No }}$

Please list all regulatory bodies involved in regulating/overseeing the electricity sector (including the ministry and/or incumbent if they are responsible for some areas of regulation) and the areas of regulation that they are responsible for.

Name a

1. Main Regulator Q31a1

2. Q31a2

3. Q31a3

4. Q31a4

3.2 Does your agency oversee multiple sectors?

3.2.1 If yes, which sectors?

\section{Date of Creation c}

Q31b1

Q31c1

Q31b2

Q31c2

Q31b3

Q31c3

Q31b4

Q31c4

Yes Q32

No

-Q321

3.3 How is the regulatory body financed? (\% of regulator's budget)
Government Budget
Q33a
Levies on Companies/License Fees
Q33b
Customer levies
Q33C
Other (Please describe) Q33e

Note: Dummy if any from each source

3.4 Is the regulatory body headed by a single person or by a group of people (e.g., a regulatory board)? 
3.5 How many employees does your agency occupy?

Of these:

3.5.1 How many technicians?

Q351

3.5.2 How many engineers?

Q352

3.5.3 How many accountants?

Q353

3.5.4 How many economists?

Q354

3.5.5 How many lawyers?

Q355

3.6 Who appoints the head and/or the commissioners of the regulatory body?

President Q36

Ministry

\section{Parliament}

Other, specify

3.7 If the president or Ministry appoints the head and/or the commissioners of the regulator body, is Parliamentary approval required?................ $\quad \underline{\text { Yes }} 1$

No $\quad$ O Q37

3.8 Is head appointed for a fixed term?

$\underline{\text { Yes }}$

No

\section{Q38}

3.8.1 For how long?

Q381

3.8.2 Can head be re-appointed?

$\underline{\text { Yes }}$

Q382

No 
3.8.3 Who has the authority to fire head/commissioners? (please mark all that apply) Q383
(b) President Q38a
(b) Minister Q38b
(d) Parliament Q38c
(d) Others (please list) Q38d

3.8.4 For what reasons (e.g. incompetence, corruption, conflict of interest)? Please list: Q384a

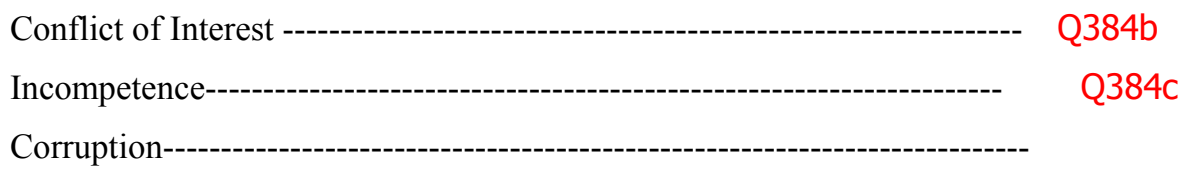

3.8.5 How many heads have been removed since your agency's creation? Q385

3.9 Who can veto the regulator's decisions? Q39a

President

$\begin{array}{ll}\text { Q39b } & \text { Minister } \\ \text { Q39c } & \text { Court } \\ \text { Q39d } & \text { Other }\end{array}$

3.10Who can issue policy guidelines for the regulator?

\begin{tabular}{|c|c|c|}
\hline Q310a = & \multicolumn{2}{|c|}{ President } \\
\hline Q310b = & \multicolumn{2}{|c|}{ Minister } \\
\hline & & Parliament \\
\hline & & $\underline{\text { Regulator }}$ \\
\hline & & Other \\
\hline
\end{tabular}

3.11 Are the policy guidelines publicly available?

Q311

$\underline{\text { Yes }}$

No

3.12Can the Minister/President give verbal instructions to the regulator?

Q312 No

3.13Have regional regulatory bodies been created? $\quad \underline{\text { Yes }}$

Q313 No 


\section{Section 4: Regulatory Process/Decisions}

4.1 Can your agency compel financial and performance information from utilities?

$$
\text { Q41 }
$$

$\underline{\text { Yes }}$

No

4.1.1 Is there a standardized reporting format for financial/performance information?

4.1.2 Is the financial/performance information audited by:
Q412a
(a) Regulator
Q412b
(b) Independent auditors
Q412c (c) Others (please list)

4.2 Does the regulator make financial and performance information publicly available?

$$
\text { Q42 }
$$

$\underline{\text { Yes }}$

No

4.3 Is there a consultation process prior to regulatory decisions? Q43 $\underline{\text { Yes/No }}$

4.3.1 If so, what type?
(a) Consultation papers Q431a
(b) Hearings Q431b
(c) Meetings Q431C
(d) Other (please list) (No other)

4.4 Please circle all groups who have the right to participate in regulatory proceedings: Q44 (Study)
(a) Consumer groups
Q44a
(b) Utilities Q44b
(c) Industry associations Q44c
(d) Others (please list) Q44d 
4.5 Can the utilities appeal if they disagree with regulator's decisions?

4.6 Who can the utilities appeal to in each instance? (i.e., Ministry, Executive, Other executive body, Judiciary, Formal domestic arbitrator, Formal international arbitrator, no appeal)

4.6.1 First instance Q46a: At what stage appeal to regulator

4.6.2 Second instance Q46b : At what stage appeal to ministry

4.6.3 Third instance Q46c: At what stage appeal to court

4.7 Can other parties appeal? $\quad$ Q47 $\quad \underline{\text { Yes }}$

No

4.8 Circle all other parties that can appeal:
Q48a (a) Consumer groups
Q48b (b) Utilities
Q48c (c) Industry associations
Q48d
(d)
Others

4.9 Are regulatory meetings open to the public in practice? Q49

$\underline{2} / \mathbf{1} / \mathbf{0}$

4.10Are regulatory meetings required to be open to the public by law? Q410 $\underline{\text { Yes/No }}$

4.11 Are regulatory decisions publicly available?

Q411

$\underline{\text { Yes/No }}$

4.12Does the law REQUIRE the regulator to publish decisions Q412

$\underline{\text { Yes/No }}$

4.13If so, where?

Q413

4.14Does the regulator publish decisions in practice? Q414

$\underline{\text { Yes/No }}$

4.14.1 If so, where? Q4141 
4.15Does the law REQUIRE the regulator to publish explanations of decisions $\underline{\text { Yes/No }}$ Q415

4.15.1 If so, where? Q4151

4.16Does the regulator publish explanations of decisions in practice?

$\underline{\text { Yes/No }}$ Q416

4.16.1 If so, where? Q4161

\section{Section 5. Price Regulation}

5.4 Are the following end-user prices regulated?
5.4.1 Electricity prices for industry?
$\underline{\text { Yes/No Q511 }}$
5.4.2 Commercial electricity prices?
Yes/No Q512
5.4.3 Electricity prices for households?
Yes/No Q513

5.5 Please provide the following information about end-user price regulation (Please mark all that apply). Q52

\begin{tabular}{|c|c|c|c|c|c|c|c|c|c|c|}
\hline \multirow[b]{2}{*}{ Prices } & \multicolumn{3}{|c|}{ R Regulator } & \multicolumn{3}{|c|}{ M $\quad$ Ministry } & \multicolumn{3}{|c|}{ P Parliament } & \multirow[b]{2}{*}{$\begin{array}{l}\text { C } \\
\text { Competi- } \\
\text { tively }\end{array}$} \\
\hline & 产 & $\begin{array}{l}\frac{n}{2} \\
\frac{0}{2} \\
\frac{2}{2}\end{array}$ & 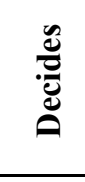 & 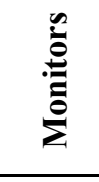 & $\begin{array}{l}\frac{y}{2} \\
\frac{0}{2} \\
\frac{2}{2}\end{array}$ & 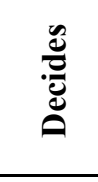 & 离 & $\frac{0}{0}$ & 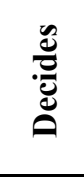 & \\
\hline & M & A & D & M & A & D & M & A & D & Decided \\
\hline Industrial I & $\begin{array}{l}\text { Q52R } \\
\text { MI }\end{array}$ & $\begin{array}{l}\text { Q52 } \\
\text { RAI }\end{array}$ & $\begin{array}{l}\text { Q52 } \\
\text { RDI }\end{array}$ & $\begin{array}{l}\text { Q52M } \\
\text { MI }\end{array}$ & $\begin{array}{l}\text { Q52M } \\
\text { AI }\end{array}$ & $\begin{array}{l}\text { Q52M } \\
\text { DI }\end{array}$ & $\begin{array}{l}\text { Q52P } \\
\text { MI }\end{array}$ & $\begin{array}{l}\text { Q52P } \\
\text { AI }\end{array}$ & $\begin{array}{l}\text { Q52 } \\
\text { PDI }\end{array}$ & Q52CI \\
\hline Residential R & $\begin{array}{l}\text { Q52R } \\
\text { MR } \\
\end{array}$ & $\begin{array}{l}\text { Q52 } \\
\text { RAR }\end{array}$ & $\begin{array}{l}\text { Q52 } \\
\text { RDR }\end{array}$ & $\begin{array}{l}\text { Q52M } \\
\text { MR } \\
\end{array}$ & $\begin{array}{l}\text { Q52M } \\
\text { AR } \\
\end{array}$ & $\begin{array}{l}\text { Q52M } \\
\text { DR } \\
\end{array}$ & $\begin{array}{l}\text { Q52P } \\
\text { MR }\end{array}$ & $\begin{array}{l}\text { Q52P } \\
\text { AR }\end{array}$ & $\begin{array}{l}\text { Q52 } \\
\text { PDR }\end{array}$ & Q52CR \\
\hline
\end{tabular}

5.6 Type of existing power market (Please mark all that apply):
Q53a (a) Bilateral contracts
Q53b
(b) Spot market
Q53c (c) Pool

Q53d

(d) Forward market

Q53e

(e) Balancing market Other

5.6.1 Is participation in the wholesale markets mandatory? Yes/No Q531

5.6.2 If so, in what type of market? Q532 
5.7 What is the price control method for:

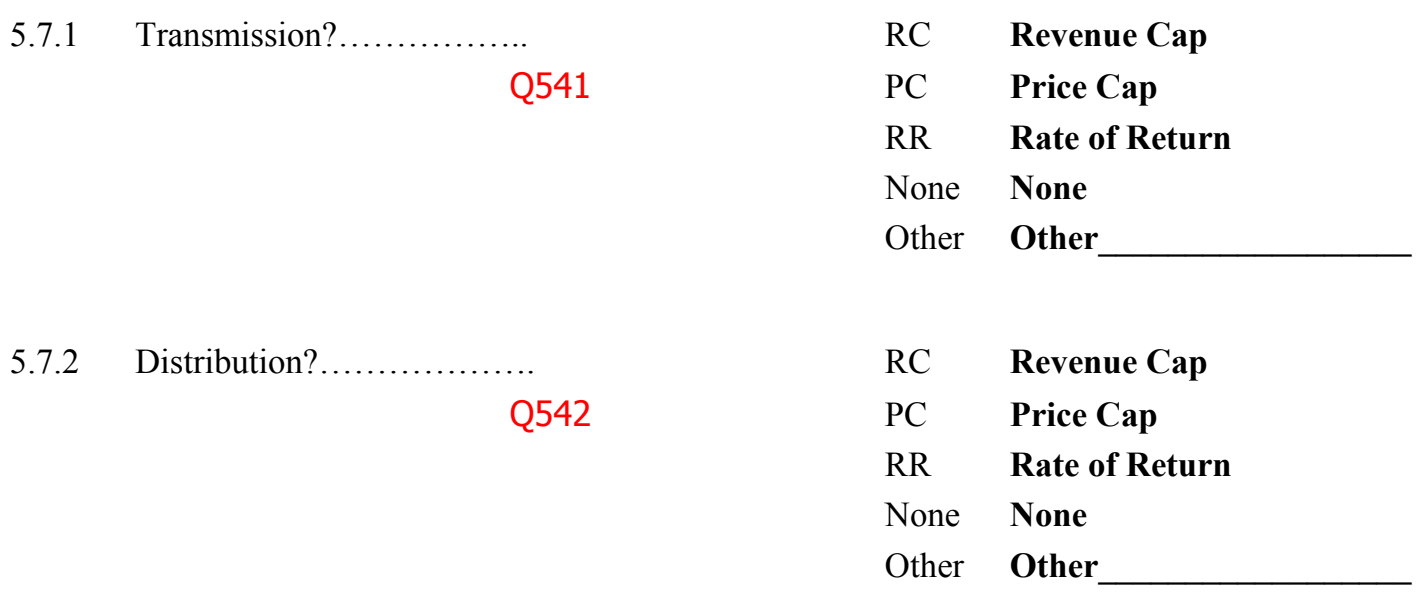

5.5 How long (in terms of years) is the period between price reviews? Q55

5.7 Does the government subsidize the use of specific generation fuels? $\quad \underline{\text { Yes/No }}$ Q56

5.7.1 If so, which? Q561
(a) Natural Gas
(b) Coal
(c) Oil
(d) Renewables

(e) Other

\section{$\underline{\text { Yes/No }}$}

5.8.1 If so, which prices?

$\begin{array}{llll}\text { Q571a (a) } & \text { Residential } & \text { Q571b (b) } & \text { Commercial } \\ \text { Q571c (c) } & \text { Industrial } & \text { Q571d (d) } & \text { Other }\end{array}$

5.8.2 What percentage of subsidies comes from the following sources? Q572 (String)

5.8.2.1 Government Budget

5.8.2.2 Industry Levies $\%$

5.8.2.3 Other (specify) $\%$

5.8.2.4 Internal X Subs 
5.9 Please fill in the following information:

\begin{tabular}{|c|c|c|c|c|}
\hline \multicolumn{5}{|c|}{ Average End-User Electricity Prices (In Local Currency Unit) } \\
\hline \multicolumn{3}{|c|}{$\begin{array}{l}\text { T0 At the time of Reform } \\
\text { Year: Q58t0y } \\
\text { (In case of no reform please enter information } 5 \\
\text { years ago) }\end{array}$} & \multicolumn{2}{|c|}{$\begin{array}{c}\text { Post-Reform } \\
\text { Year: Q58y } \\
\text { (In case of no reform please enter } \\
\text { most recent information) }\end{array}$} \\
\hline & R Residential & I $\quad$ Industrial & R Residential & I $\quad$ Industrial \\
\hline Generation & Q58t0RG & Q58t0IG & Q58RG & Q58IG \\
\hline Transmission & Q58t0RT & Q58t0IT & Q58RT & Q58IT \\
\hline Distribution & Q58t0RD & Q58t0ID & Q58RD & Q58ID \\
\hline Supply & Q58t0RS & Q58t0IS & Q58RS & Q58IS \\
\hline Total & Q58t0R & Q58t0I & Q58R & Q58I \\
\hline
\end{tabular}

\section{Section 6. Access/Interconnection Policies}

6.6 Does the law require non-discriminatory access to transmission and distribution networks (Third Party Access

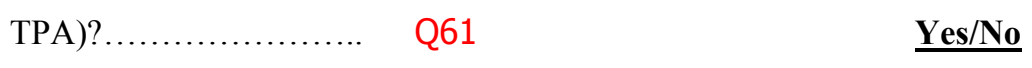

6.7 Does the law require that all entrants receive the same technical terms and conditions for access?........................... Q62 $\quad$ Yes/No

6.8 Does the law require that all entrants receive the same prices for access? $\quad \underline{\text { Yes/No }}$ Q63

6.9 How are access fees/interconnection rates set between the generation and transmission/distribution operators?

\section{Q64 Negotiated TPA}

\section{Regulated TPA}

\section{Other (specify):}

6.10If operators cannot agree on access/interconnection terms/fees, who can intervene to resolve conflicts?.

Q65

6.11 Is transmission access controlled by an independent system operator (ISO)? Q66 $\underline{\text { Yes/No }}$ 
6.12Is the transmission network operator required to extend the network to meet demand?

Q67

$\underline{\text { Yes/No }}$

\section{Section 7: Licenses}

7.11 Is there a formal procedure for granting/renewing licenses for the following areas?

$\begin{array}{lllr}7.11 .1 & \text { Generation? } & \text { Q711 } & \underline{\text { Yes/No }} \\ 7.11 .2 & \text { Transmission? } & \text { Q712 } & \underline{\text { Yes/No }} \\ 7.11 .3 & \text { Distribution? } & \text { Q713 } & \underline{\text { Yes/No }} \\ 7.11 .4 & \text { Retail Supply? } & \text { Q714 } & \underline{\text { Yes/No }} \\ 7.11 .5 & \text { Imports? } & \text { Q715 } & \underline{\text { Yes/No }} \\ 7.11 .6 & \text { Exports? } & \text { Q716 } & \underline{\text { Yes/No }}\end{array}$

7.12 Who approves licenses?

\begin{tabular}{|l|l|l|l|l|l|l|}
\hline & Regulator & President & Ministry & Parliament & $\begin{array}{c}\text { Other (please } \\
\text { specify) }\end{array}$ \\
\hline Q72g & Generation & & & & & \\
\hline Q72T & Transmission & & & & & \\
\hline Q72D & Distribution & & & & \\
\hline Q72S & Retail Supply & & & & & \\
\hline Q72M & Imports & & & & & \\
\hline Q72X & Exports & & & & & \\
\hline
\end{tabular}

7.13 Is there a mandatory bidding for granting licenses?

$\begin{array}{llcc}7.13 .1 & \text { Generation? } & \text { Q731 } & \underline{\text { Yes/No/No Experience }} \\ 7.13 .2 & \text { Transmission? } & \text { Q732 } & \underline{\text { Yes/No/No Experience }} \\ 7.13 .3 & \text { Distribution? } & \text { Q733 } & \underline{\text { Yes/No/No Experience }} \\ 7.13 .4 & \text { Retail Supply? } & \text { Q734 } & \underline{\text { Yes/No/No Experience }} \\ 7.13 .5 & \text { Imports? } & \text { Q735 } & \underline{\text { Yes/No/No Experience }} \\ 7.13 .6 & \text { Exports? } & \text { Q736 } & \underline{\text { Yes/No/No Experience }}\end{array}$

7.14Can a license be revoked? $\quad$ Q74 $\quad \underline{\text { Yes/No }}$ 
7.14.1 If yes for what reason? Q741

\section{Section 8: Universal Service Obligations/Quality of Supply}

8.1 Are utilities allowed to cut-off service for non-payment? Q81 $\underline{\text { Yes/No }}$

8.2 Is there a clearly stated policy addressing issues such as:
Q82a
(a) Non-Payment/Credit problems Q82b
(b) Cost of new connections
Q82C (c) Support of low-income groups
Q82d
(d) Supply of rural customers
Q82e (e)
(e) Non-discrimination among consumers
Other

8.2 What are the bodies involved in protection consumer interests? (please mark all that apply)

Q821a (a) Independent interest/consumer groups Q821b (b) Regulator

Q821c (c) Other government agencies

Others

8.3 Are there well-defined targets or minimum standards for quality of service (e.g. number of interruptions, minutes lost per customer, SAIFI, SAIDI, etc)? Q83

$\underline{\text { Yes/No }}$ 


\subsubsection{If so, are there well-defined penalty schemes for non-compliance? $\quad \underline{\text { Yes/No }}$ Q831}

8.3.2 Have there been any quality of service improvements after reform? $\quad \underline{\text { Yes/No }}$ Q832

8.3.2.1 If yes, please describe improvements:

Q8321

8.6 Number of connections/customers: Q86

8.6 Please enter the following information:

\begin{tabular}{|c|c|c|c|}
\hline \multicolumn{4}{|c|}{ Degree of Electrification (e.g. \% of population, \% of households) } \\
\hline $\begin{array}{c}\text { At the time of Reform } \\
\text { (In case of no reform please enter information 5 years } \\
\text { ago) }\end{array}$ & \multicolumn{3}{|c|}{$\begin{array}{c}\text { Post-Reform } \\
\text { (In case of no reform please enter most recent } \\
\text { information) }\end{array}$} \\
\hline \begin{tabular}{c|c|c|c|} 
\% (specify indicator) \\
Q86t0 (specify indicator)
\end{tabular} & Year \\
\hline
\end{tabular}

\section{Section 9: Sector Characteristics}

9.1 Please fill in the following sector information:

\begin{tabular}{|c|c|c|}
\hline \multicolumn{3}{|c|}{ Resource Base (Generation) } \\
\hline Q91 & $\begin{array}{c}\text { to At the time of Reform } \\
\text { Year:Q91t0y } \\
\text { (In case of no reform please enter information } \\
5 \text { years ago) }\end{array}$ & $\begin{array}{c}\text { Post-Reform } \\
\text { Year: Q91y } \\
\text { (In case of no reform please enter most recent } \\
\text { information) }\end{array}$ \\
\hline Generation Type & Installed Capacity in MW & Installed Capacity in MW \\
\hline O $\quad$ Oil & Q91t00 & Q910 \\
\hline C Coal & Q91t0C & Q91C \\
\hline G Natural Gas & Q91t0G & Q91G \\
\hline H $\quad$ Hydro & Q91t0H & $\mathrm{Q} 91 \mathrm{H}$ \\
\hline N $\quad$ Nuclear & Q91t0N & Q91N \\
\hline OTH Other & Q91t0OTH & Q910TH \\
\hline
\end{tabular}

\subsection{System Losses:}




\begin{tabular}{|c|c|c|c|}
\hline \multicolumn{4}{|c|}{ Transmission/Distribution Losses } \\
\hline \multicolumn{2}{|c|}{$\begin{array}{c}\text { At the time of Reform } \\
\text { (In case of no reform please } \\
\text { enter information } 5 \text { years ago) }\end{array}$} & \multicolumn{2}{|c|}{$\begin{array}{c}\text { Post-Reform } \\
\text { (In case of no reform enter } \\
\text { current information) }\end{array}$} \\
\hline (MWh) & Year & (MWh) & Year \\
\hline Q92t0 & Q92t0y & Q92 & Q92y \\
\hline
\end{tabular}

+ Shr $=$ Percentage

Q92t0t $=$ trans losses $\quad$ Q92t0Tshr $=$ pct losses trans

Q92t0d $=$ dist. losses $\quad$ Q92t0dshr $=$ pct losses dist

9.3 Please fill in the following tables:

\begin{tabular}{|c|c|c|c|c|c|}
\hline & \multirow[b]{2}{*}{ Q93 } & \multicolumn{2}{|c|}{ E Number of full-time sector employees } & \multicolumn{2}{|c|}{$\begin{array}{l}\text { M } \quad \text { MWh } \\
\text { (Generated, transmitted, distributed, sold) }\end{array}$} \\
\hline & & $\begin{array}{l}\text { At the time of Reform } \\
\text { Year: Q93Et0y } \\
\text { (In case of no reform } \\
\text { please enter information } \\
5 \text { years ago) }\end{array}$ & $\begin{array}{c}\text { Post-Reform } \\
\text { Year: Q93Ety } \\
\text { (In case of no reform } \\
\text { please enter most recent } \\
\text { information) }\end{array}$ & $\begin{array}{l}\text { At the time of Reform } \\
\text { Year: Q93Møy } \\
\text { (In case of no reform } \\
\text { please enter information } \\
5 \text { years ago) }\end{array}$ & $\begin{array}{c}\text { Post-Reform } \\
\text { Year: Q93My } \\
\text { (In case of no reform please } \\
\text { enter most recent } \\
\text { information) }\end{array}$ \\
\hline $\mathbf{G}$ & Generation & Q93Et0G & Q93EG & Q93Mt0yG & Q93MG \\
\hline$T$ & Transmission & Q93Et0T & Q93ET & Q93Mt0yT & Q93MT \\
\hline D & Distribution & Q93Et0D & Q93ED & Q93Mt0yD & Q93MD \\
\hline $\mathbf{S}$ & Supply & O93Et0S & O93ES & o93Mt0ys & O93MS \\
\hline & Total & Q93Et0 & Q93E & Q93Mt0 & Q93M \\
\hline
\end{tabular}

\begin{tabular}{|l|l|l|l|l|l|}
\hline & & G & R & \multicolumn{2}{|c|}{ Retail Supply } \\
\cline { 2 - 6 } & Companies & $\begin{array}{l}\text { M } \\
\text { Market Share (\%) }\end{array}$ & $\begin{array}{l}\text { O Ownership Status } \\
\text { State-owned, minority private, } \\
\text { majority private, private) }\end{array}$ & $\begin{array}{l}\text { M } \\
\text { Market Share (\%) }\end{array}$ & $\begin{array}{l}\text { O State-owned, minority private, } \\
\text { majority private, private) }\end{array}$ \\
\hline $\mathbf{1}$ & Largest & Q931GM1 & Q931GO1 & Q931RM1 & Q931RO1 \\
\hline $\mathbf{2}$ & Second Largest & Q931GM2 & Q931GO2 & Q931RM2 & Q931RO2 \\
\hline $\mathbf{3}$ & Third Largest & Q931GM3 & Q931GO3 & Q931RM3 & Q931RO3 \\
\hline
\end{tabular}


Comments: 


\section{THANK YOU VERY MUCH FOR YOUR HELP}

